\title{
Monitoring of continuous GNSS stations in Central Anatolia region
}

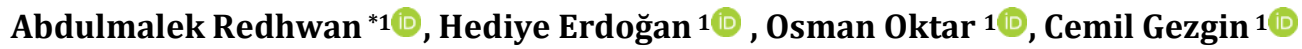 \\ ${ }^{1}$ Aksaray University, Faculty of Engineering, Department of Geomatics Engineering, Aksaray, Turkey
}

\author{
Keywords \\ GNSS \\ ITRF \\ Central Anatolia Region \\ Time Series Analysis \\ Trend Component \\ Analysis
}

\begin{abstract}
In this study, the linear behaviors in the North, East and Up directions of 30 CORS-TR stations in the Central Anatolian Region were obtained by the trend component analysis which is the time series component. The time series of the stations between 2017-2020 years were calculated in the Eurasia-fixed frame with the GAMIT/GLOBK software. As a result of the analysis, the average horizontal velocity of the stations in the east of the Central Anatolian Region is $17.59 \mathrm{~mm} /$ year in the northwest direction, and the average horizontal velocity of the stations in the west is $18.66 \mathrm{~mm} /$ year in the southwest direction. This movement shows the movement of the Anatolian plate in the southwest direction in terms of direction and velocity and is in agreement with other research results. In the linear changes in the up coordinates of the stations, the greatest linear change was detected at the KNY1 ( $-48.22 \mathrm{~mm} /$ year) station. It is thought that this change at station KNY1 is due to the decrease in groundwater level in this region (Konya Closed Basin). In addition, in the standard deviation $\left(\mathrm{m}_{0}\right)$ values of the time series that obtained as a result of the analysis, linear changes were approximately the same for the north and east directions, and about 2-3 times larger for the up values compared to the north or east directions.
\end{abstract}

\section{INTRODUCTION}

As one of the most tectonically active regions of the world, Turkey is located in an active earthquake zone. It is quite possible to encounter fault zones in engineering studies. Two of the most important (active) faults in Turkey are the North Anatolian and East Anatolian Fault Zones. The North Anatolian Fault (NAF), which extends from Karlıova in eastern Turkey to Saros Bay in the North Aegean Sea, is one of the longest active strike-slip faults in the world with a length of approximately $1500 \mathrm{~km}$ (Yavaşoğlu et al., 2011).

As it is known, due to the fact that Turkey is located at the intersection of the Arabian, Anatolian and Eurasian tectonic plates, annual changes (plate velocity) occur due to the movement of these plates in $\mathrm{cm}$ order at point locations. For this reason, it is important to determine the point location information accurately, continuously, quickly and economically with reliable methods and to present it to the relevant users who do both commercial and scientific studies in location-based studies.
Today, Global Navigation Satellite Systems (GNSS) are widely used to determine point locations. In particular, it has a wide range of uses such as tectonic movements, land subsidence, engineering services, scientific studies, aviation industry, navigation, vehicle tracking systems, military areas, and therefore has a large number of users (Uzel et al., 2013; Oktar and Erdoğan, 2018; Mutlu and Kahveci, 2019; Gezgin et al., 2020; Yalvaç, 2020; Orhan, 2021).

There are also many error sources that GNSS systems with reliable location services are exposed to. These are satellite-related such as satellite clock error, satellite orbital errors; errors originating from the receiver such as receiver clock error, antenna phase center error, and atmospheric errors such as tropospheric effect, ionospheric effect, signal reflection effect. The effect of these error sources on the results can be neglected according to the sensitivity of the work being done. However, in applications where precision is required such as geodetic studies, tectonic studies, continental deformations, it is important to create a

\footnotetext{
* Corresponding Author

*(abdulmalekredhwan2017@gmail.com) ORCID ID 0000-0003-3921-0315 (hediye.erdogan@aksaray.edu.tr) ORCID ID 0000-0002-6470-5857 (osmanoktar@aksaray.edu.tr) ORCID ID 0000-0001-6764-0561 (cemilgezgin.jfm@gmail.com) ORCID ID 0000-0002-5951-0107 of Geosciences 2(2), 21-29. 
mathematical model of these errors to eliminate the error sources (Mutlu and Kahveci, 2019).

In this study, the behaviors of 30 Continously Operating Reference Stations-Turkey (TUSAGAAktif/CORS-TR) stations in the Central Anatolia Region were investigated with linear trend function. The coordinates of the stations were produced from the daily time series obtained between years of 2017-2020. The coordinates of the stations are the time series obtained daily between 2017 and 2020 for the Eurasia fixed-frame. The velocity values and directions of the region were estimated in the Eurasia fixed-frame by liner trend component of the time series analysis.

\section{CENTRAL ANATOLIA EARTHQUAKE ZONE}

Kırşehir, which is located in the great arc of Kızılırmak in Central Anatolia and consists of metamorphic and platonic rocks, seems to have been divided into blocks from many parts by faults. The parts between the blocks were filled with Neogene sediments. These regions formed by faults are the main earthquake belts of Central Anatolia and 1938 Kırşehir earthquake occurred in this region. In this earthquake, 160 people lost their lives and 4066 buildings were destroyed or severely damaged. In addition to that 50 people died in the 1951 Kurşunlu (Çankırı) earthquake (Özdoğan, 1993).

Also, in the north of Ankara, faults in the northeast-southwest direction form parallel fracture zones in the direction of Kızllcahamam-Güdül-Ayaş and Çamlidere-Beypazarı. This shows that in the earthquakes in Central Anatolia, in addition to the "North Anatolian Earthquake Zone", the independent earthquake centers also have significant effects. Because the 1944 Beypazarı and 1956 Eskişehir earthquakes are the results of an independent earthquake center. Another fault zone in Central Anatolia is located in the west of Tuz Gölü. Fractures running parallel to each other formed a belt. However, earthquakes causing massive damage were not detected either in Konya and its surroundings or in other settlements in this area (Özdoğan, 1993).

\section{TIME SERIES ANALYSIS}

Time series analysis provides useful information about the behavior of systems based on response or effect size. The sequential realization of the observed data over time is very important in terms of monitoring and analyzing the development of the data (Ostini, 2012).

In general, the $\mathrm{X}\left(\mathrm{t}_{\mathrm{i}}\right)$ time series of measurements made at GNSS stations at times $t_{i}(i=1,2,3, \ldots, N)$ can be divided into three components, excluding artificial or co-seismic and seismic-induced deviations. These components are given in equation (1).

$X\left(t_{i}\right)=Y\left(t_{i}\right)_{\text {trend }}+Y\left(t_{i}\right)_{\text {periodic }}+Y\left(t_{i}\right)_{\text {stochastic }}$
In time series analysis, firstly the time axis of the series is plotted, unusual measurements (e.g. gross errors) in the series are eliminated and a general interpretation of the series can be made (Oktar, 2015).

\subsection{Trend Component}

Trend is the development or progress of a time series in a certain direction in the long run. The direction and intensity of the trend do not always remain constant. The trend can be linear or curvilinear (Equation 2).

$Y\left(t_{i}\right)=\underbrace{a+b t}_{(1) \text { Trend Component }}$

Here, "a" constant and "b" are the parameters that show the amount and direction of linear change with time. For GNSS stations, the increasing or decreasing linear changes (velocities) of the GNSS stations are determined with the "b" parameter. Considering the linear function given in Equation 2 for the estimation of the parameters in the time series $\mathrm{Y}\left(\mathrm{t}_{\mathrm{i}}\right)$.

$$
\begin{aligned}
Y\left(t_{i}\right) & =a+b t \\
& =\boldsymbol{A} \boldsymbol{x}+\boldsymbol{v}\left(\boldsymbol{t}_{i}\right) \\
\boldsymbol{A}^{T}= & {\left[\begin{array}{ccc}
\mathbf{1} & \mathbf{1} & \mathbf{1}, \ldots, N \\
\boldsymbol{t}_{1} & \boldsymbol{t}_{2} & \boldsymbol{t}_{3}, \ldots, \boldsymbol{t}_{N}
\end{array}\right], \boldsymbol{X}^{T}=\left[\begin{array}{ll}
\boldsymbol{a} \\
b
\end{array}\right] }
\end{aligned}
$$

According to the least squares method, parameters "a", "b" and their standard deviations $m_{a}$ and $m_{b}$ are estimated. Test size values are calculated for each parameter.

$t_{a}=\frac{a}{m_{a}} ; t_{b}=\frac{b}{m_{b}}$

The predicted 1- $\alpha$ confidence level for the test sizes and the $t_{f}, 1-\alpha / 2$ confidence limit of the $t$ distribution depending on the $f$ degree of freedom are compared.

$\left|t_{a}\right| ;\left|t_{b}\right|<t_{f, 1-\alpha / 2}$

If the situation is as seen in the equation given in 7 , the parameters are insignificant,

$\left|t_{a}\right| ;\left|t_{b}\right| \geq t_{f, 1-\alpha / 2}$

If the values above test size, parameters are significant at the estimated confidence level. If the parameters are statistically significant, it is decided that there is a trend component in the series.

In the process of determining the trend component in the time series, it is not possible to determine the existence of linear change and to accurately detect some periodic movements due to the long period of time for a full periodic movement to occur. For this reason, it is very important that the 
measurements are made as long as necessary to reflect the changes in the monitored system, data or the existence of the trend must be interpreted correctly.

\section{STUDY FINDINGS AND DISCUSSION}

In this study, the linear behaviors of 30 TUSAGA-Aktif/CORS-TR stations in the Central Anatolia Region covering the years of 2017-2020 were investigated with the trend component function, which is the time series component. To this end; N (North), E (East) and U (Up) components of daily coordinate times series of the stations; AKD1, AKHR, AKSR, ANK2, ANRK, BEYS, BOG1, CANK, CIHA, CMLD, ESKS, GEME, GURU, HALP, KAMN, KAP1, KAYS, KIS1, KKAL, KLUU, KNY1, NAHA, NEV1, NIGD, SARV, SIH1, SIVS, SSE1, YOZ1 and YUN1 were used.

With the linear functions applied to the obtained time series, the linear changes (velocity values) of the stations in the determined time interval were calculated, and the linear behavior and functions of the stations were defined in the Eurasia Fixed system. General information about the IGS stations (14 sites) used in the processing is given in Table 1. GNSS data were evaluated with GAMIT/GLOBK software, an open-source software package developed by Massachusetts Institute of Technology (MIT) (Url-1). In the processing, for orbit information, Precise final orbits by the International Global Navigation Satellite Systems (GNSS) Service (IGS), for earth rotation parameters USNO_bull_b, for radiation and pressure effects 9-parameter Berne model was used. LC (L3), that is the ionosphere-free linear combination of the L1 and L2 carrier waves, and the FES2004 Ocean Tide Loading (OTL) grid was used. Time series of stations were obtained using
RINEX data that acquired from the web interface given in Url-2.

Table 1. IGS stations used in the processing

\begin{tabular}{|l|l|l|l|}
\hline Station & City/ Country & Station & City / Country \\
\hline ANKR & $\begin{array}{l}\text { Ankara/ } \\
\text { Turkey }\end{array}$ & MATE & Matera/ Italy \\
\hline BAKU & $\begin{array}{l}\text { Baku/ } \\
\text { Azerbaijan }\end{array}$ & NICO & $\begin{array}{l}\text { Nicosia/ South } \\
\text { Cyprus }\end{array}$ \\
\hline BUCU & $\begin{array}{l}\text { Bucharest/ } \\
\text { Romania }\end{array}$ & RAMO & $\begin{array}{l}\text { MitzpeRamon/ } \\
\text { Israel }\end{array}$ \\
\hline CRAO & $\begin{array}{l}\text { Simeiz/ } \\
\text { Ukraine }\end{array}$ & SOFI & Sofia/ Bulgaria \\
\hline GLSV & $\begin{array}{l}\text { Kiev/ } \\
\text { Ukraine }\end{array}$ & TEHN & Tehran/ Iran \\
\hline GRAZ & Graz/Austria & TELA & Tel Aviv/ Israel \\
\hline ISTA & $\begin{array}{l}\text { İstanbul/ } \\
\text { Turkey }\end{array}$ & TUBI & Gebze/ Turkey \\
\hline
\end{tabular}

\subsection{The Field Study and Data}

In this study, daily coordinate data of the 30 GNSS stations such as AKD1, AKHR, AKSR, ANK2, ANRK, BEYS, BOG1, CANK, CIHA, CMLD, ESKS, GEME, GURU, HALP, KAMN, KAP1, KAYS, KIS1, KKAL, KLUU, KNY1, NAHA, NEV1, NIGD, SARV, SIH1, SIVS, SSE1, YOZ1 and YUN1 were used in the analysis that located in the Central Anatolia Region. Location information of the stations are given in Figure 1 and Table 2. The GNSS data used in the study are the daily coordinate values between 01.01.2017 and 31.12.2020, and the data information of the stations are given in Table 3 . In the evaluations and analyzes, there were data deficiencies and gaps between years in the daily coordinate data of GNSS stations between 01.01.2017-31.12.2020 due to reasons such as antenna defect, computer malfunction, etc.

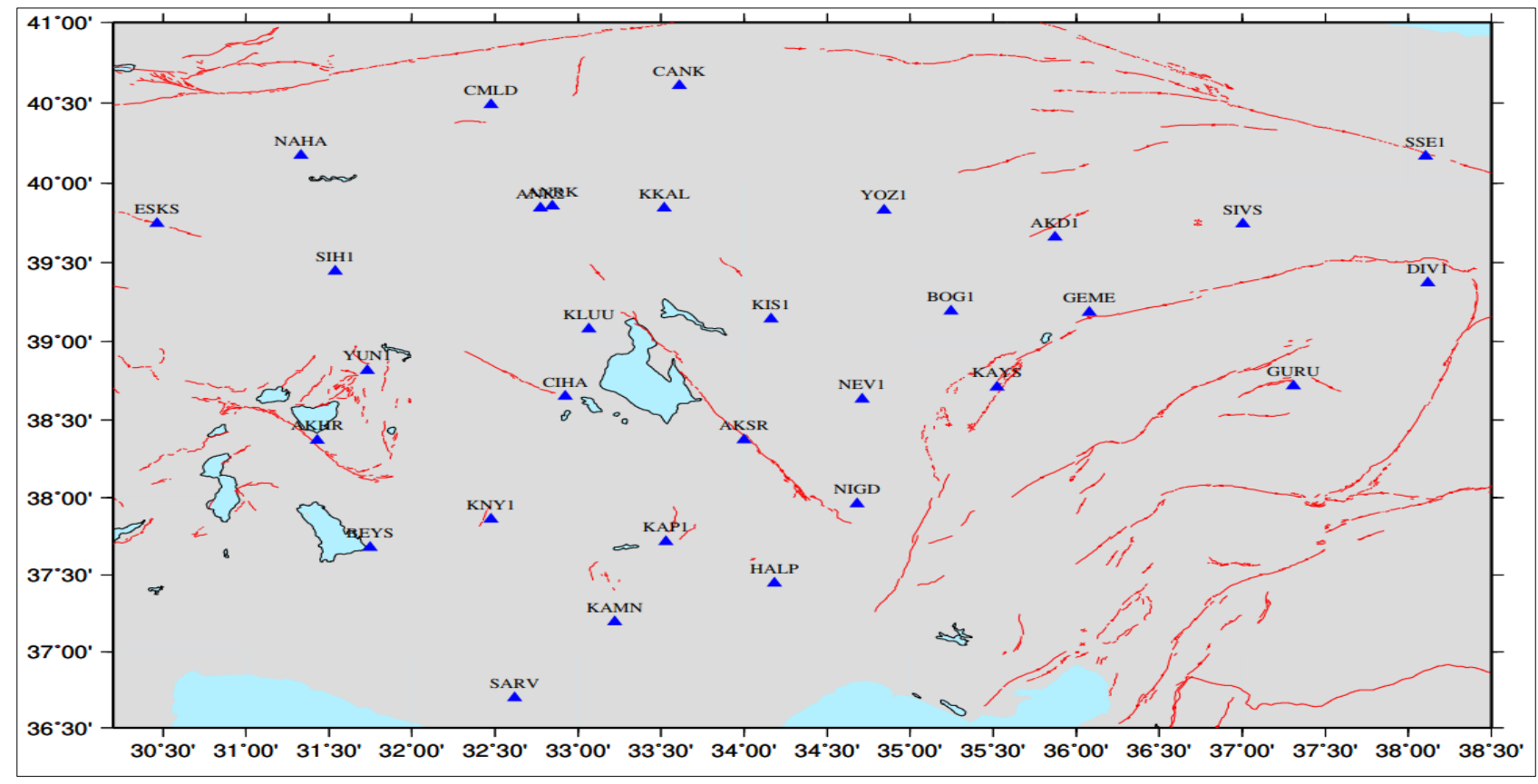

Figure 1. GNSS stations locations 
Table 2. GNSS stations general information

\begin{tabular}{|l|l|l|l|l|l|l|l|}
\hline $\begin{array}{l}\text { Short } \\
\text { Name }\end{array}$ & City/ Town & $\begin{array}{l}\text { Latitude } \\
\text { (Decimal } \\
\text { Degree) }\end{array}$ & $\begin{array}{l}\text { Longitude } \\
\text { (Decimal } \\
\text { Degree) }\end{array}$ & $\begin{array}{l}\text { Short } \\
\text { Name }\end{array}$ & City/ Town & $\begin{array}{l}\text { Latitude } \\
\text { (Decimal } \\
\text { Degree) }\end{array}$ & $\begin{array}{l}\text { Longitude } \\
\text { (Decimal } \\
\text { Degree) }\end{array}$ \\
\hline AKD1 & Yozgat/Akdağmadeni & 39.6605 & 35.8711 & KAP1 & Konya/Karapınar & 37.7144 & 33.5283 \\
\hline AKHR & Konya/Akșehir & 38.3693 & 31.4297 & KAYS & Kayseri/Melikgazi & 38.7137 & 35.5031 \\
\hline AKSR & Aksaray/Merkez & 38.3704 & 33.9982 & KIS1 & Kırșehir/Merkez & 39.1434 & 34.1631 \\
\hline ANK2 & Ankara/Çankaya & 39.8428 & 32.7754 & KKAL & Kırıkkale/Merkez & 39.8433 & 33.5179 \\
\hline ANRK & Ankara/Çankaya & 39.8560 & 32.8462 & KLUU & Konya/Kulu & 39.0791 & 33.0654 \\
\hline BEYS & Konya/Beyşehir & 37.6773 & 31.7466 & KNY1 & Konya/Meram & 37.8594 & 32.4764 \\
\hline BOG1 & Yozgat/Boğazlıyan & 39.1933 & 35.2471 & NAHA & Ankara/Nallınan & 40.1733 & 31.3321 \\
\hline CANK & Çankır//Merkez & 40.6086 & 33.6104 & NEV1 & Nevşehir/Merkez & 38.6315 & 34.7108 \\
\hline CIHA & Konya/Cihanbeyli & 38.6504 & 32.9224 & NIGD & Niğde/Merkez & 37.9588 & 34.6794 \\
\hline CMLD & Ankara/Çamlıdere & 40.4910 & 32.4745 & SARV & Karaman/Sarıeliler & 36.6967 & 32.6173 \\
\hline DIV1 & Sivas/Divriği & 39.3718 & 38.1194 & SIH1 & Eskișehir/Sivrihisar & 39.4465 & 31.5363 \\
\hline ESKS & Eskișehir/Turgutlar & 39.7457 & 30.4636 & SIVS & Sivas/Merkez & 39.7437 & 37.0025 \\
\hline GEME & Sivas/Gemerek & 39.1851 & 36.0809 & SSE1 & Sivas/Suşehri & 40.1691 & 38.1050 \\
\hline GURU & Sivas/Gürün & 38.7174 & 37.3079 & YOZ1 & Yozgat/Merkez & 39.8314 & 34.8447 \\
\hline HALP & Konya/Halkapınar & 37.4451 & 34.1834 & YUN1 & Konya/Yunak & 38.8162 & 31.7317 \\
\hline KAMN & Karaman/Merkez & 37.1932 & 33.2203 & & & &
\end{tabular}

Data numbers and missing data percentages of these stations are given in Table 3. Data percentages of other stations are certain except AKD1, ANRK, BOG1, CANK, CMLD, KAP1, KAYS, KIS1, SARV, SIH1,
SIVS, YOZ1 and YUN1. In addition, since KIS1 and ANK2 stations are newly established, their data is used for 1 year, AKD1 station for 2 years, BOG1, NEV1 and SSE1 for 3 years.

Table 3. GNSS stations data and percentages

\begin{tabular}{|l|l|l|l|l|l|l|l|l|l|}
\hline $\begin{array}{l}\text { Station } \\
\text { Name }\end{array}$ & Beginning & Finish & $\begin{array}{l}\text { Number } \\
\text { of Data }\end{array}$ & $\begin{array}{l}\text { Missing } \\
\text { Data(\%) }\end{array}$ & $\begin{array}{l}\text { Station } \\
\text { Name }\end{array}$ & Beginning & Finish & $\begin{array}{l}\text { Number } \\
\text { of Data }\end{array}$ & $\begin{array}{l}\text { Missing } \\
\text { Data(\%) }\end{array}$ \\
\hline AKD1 & 01.01 .2019 & 31.12 .2020 & 620 & 0.8 & KAP1 & 19.06 .2017 & 31.12 .2020 & 1268 & 0.9 \\
\hline AKHR & 01.01 .2017 & 31.12 .2020 & 1460 & 0 & KAYS & 01.01 .2017 & 31.12 .2020 & 1436 & 1 \\
\hline AKSR & 01.01 .2017 & 31.12 .2020 & 1455 & 0 & KIS1 & 12.02 .2020 & 31.12 .2020 & 323 & 0.9 \\
\hline ANK2 & 01.01 .2020 & 31.12 .2020 & 365 & 0 & KKAL & 01.01 .2017 & 31.12 .2020 & 1460 & 0 \\
\hline ANRK & 01.01 .2017 & 31.12 .2020 & 1435 & 1 & KLUU & 01.01 .2017 & 31.12 .2020 & 1460 & 0 \\
\hline BEYS & 01.01 .2017 & 31.12 .2020 & 1460 & 0 & KNY1 & 01.01 .2017 & 31.12 .2020 & 1460 & 0 \\
\hline BOG1 & 01.01 .2018 & 31.12 .2020 & 1095 & 0.7 & NAHA & 01.01 .2017 & 31.12 .2020 & 1460 & 0 \\
\hline CANK & 01.01 .2017 & 31.12 .2020 & 1431 & 0.9 & NEV1 & 01.01 .2018 & 31.12 .2020 & 1095 & 0 \\
\hline CIHA & 01.01 .2017 & 31.12 .2020 & 1460 & 0 & NIGD & 01.01 .2017 & 31.12 .2020 & 1460 & 0 \\
\hline CMLD & 01.01 .2017 & 31.12 .2020 & 1411 & 1 & SARV & 01.01 .2017 & 31.12 .2020 & 1263 & 0.9 \\
\hline ESKS & 01.01 .2017 & 31.12 .2020 & 1460 & 0 & SIH1 & 01.01 .2017 & 25.06 .2020 & 1047 & 0.7 \\
\hline GEME & 01.01 .2017 & 31.12 .2020 & 1460 & 0 & SIVS & 01.01 .2017 & 31.12 .2020 & 1169 & 0.8 \\
\hline GURU & 01.01 .2017 & 31.12 .2020 & 1460 & 0 & SSE1 & 01.01 .2018 & 31.12 .2020 & 1095 & 0 \\
\hline HALP & 01.01 .2017 & 31.12 .2020 & 1460 & 0 & YOZ1 & 01.01 .2017 & 31.12 .2020 & 1405 & 1 \\
\hline KAMN & 01.01 .2017 & 31.12 .2020 & 1460 & 0 & YUN1 & 01.01 .2017 & 31.12 .2020 & 1397 & 1 \\
\hline
\end{tabular}

\subsection{GNSS Stations Time Series}

For the time series analysis, BASK, SIVS, YAZ1, CANK, ANRK, CALM, AKD1 and YUN1 stations were considered as two data groups, and SARV and SIH1 stations as three data groups due to the large data gaps in some of the stations. The time interval of time series data obtained by taking Eurasia plate as constant is given in Table 3.

In this study, raw coordinate time series were created by subtracting the first coordinate value from all coordinates in order to see the change of raw coordinates relative to the beginning.

In Figure 2, 3 and 4, it is clearly seen that the time series of KAP1 North (increase), East (decrease) and Up (decrease) raw coordinates contain a linear movement, and in addition, a one (1) year periodic movement is seen in the time series of the northing coordinates. Times series of the remaining stations are not given in this study due to the large number of data and figures. 


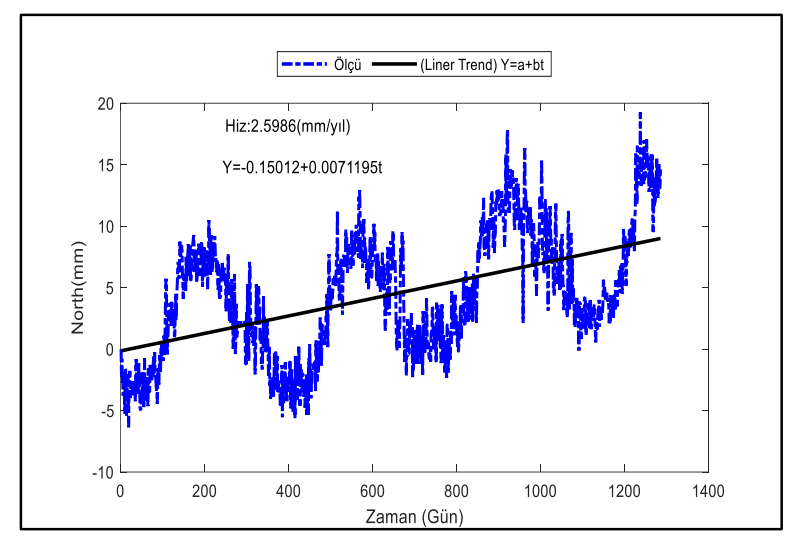

Figure 2. KAP1 North coordinate component linear model

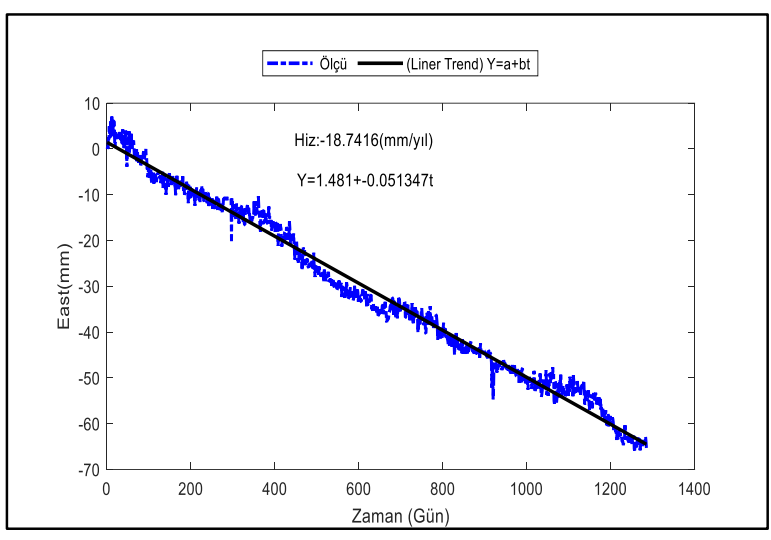

Figure 3. KAP1 East coordinate component linear model

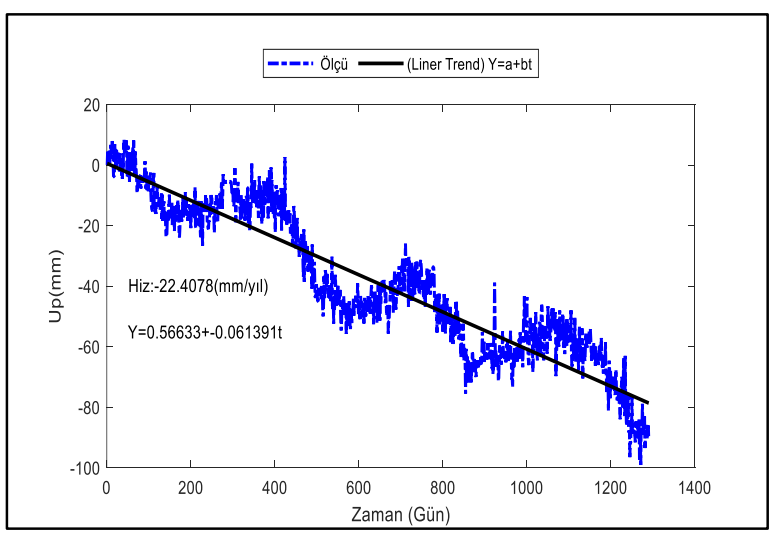

Figure 4. KAP1 Up coordinate component linear model

The linear trend component analysis of the time series was performed by calculating the "a" and "b" parameters and standard deviations given in Equation 3.2 according to the least squares method. The calculated test sizes were compared with the $\alpha=0.05$ significance level and the $t_{f, 1-\alpha / 2}$ confidence limit of the $t$ distribution depending on the $f$ degree of freedom, and statistically significant linear movements were detected in the time series of all GNSS stations. Obtained results and functions are given in Table 4.

When Table 4 is examined, it is seen that CANK_1, CIHA, ANRK_1, ANKR, SERV_2, CALM_1, CALM_2, BEYS, YUN1_1, YUN1_2, SIH1_1, SIH1_2, SIH1_3, AKHR, NAHA, ESKS, BUCU and ANK2 stations have linear movements in the south direction, while the other stations have linear movements in the north direction.

The eastward movements were detected in stations; BASK_1, BASK_2, GURU, SIVS_1, SIVS_2, GEME, KAYS, YOZ1_1, YOZ1_2, NIGD, HALP, AKSR, CANK_1, CANK_2, KKAL, KAMN, KLUU, CIHA, ANRK_1, ANRK_2, ANKR, SARV1, SARV_2, SARV_3, CALM_1, CALM_2, BEYS, YUN1_1, YUN_2, SIH1_1, SIH1_2, AKHR, NAHA, ESKS, BOR1, KAP1, BOG1, NIV1, AKD1_1, AKD1_2, ANK2, KIS1 and westward movements were detected at SIH1_3 and BUCU stations. The largest linear movement in the west direction (23.29 mm/year) was detected at ANKR station, and the smallest linear movement $[0.36$ $\mathrm{mm}$ /year) was detected at BUCU station.

In addition, the largest annual linear movement in the north direction of $15.51 \mathrm{~mm}$ was observed at BASK_1 station, and the smallest annual linear movement in the south direction of $0.06 \mathrm{~mm}$ was observed at ANRK_1 station. Considering the linear movements in the time series of the Up coordinates of the stations; (Table 4) BASK_1, BASK_2, SIVS_1, SIVS_2, GEME, KAYS, YOZ1_1, YOZ1_2, NIGD, HALP, KKAL, KLUU, ANRK_1, ANRK_2, SARV_2, SARV_3, CALM_1, CALM_2, BEYS, YUN1_1, YUNH1_2, KSSI, BUCU, SSE1, AKD1_2 and ANK2 linear movements in the direction were observed in the positive direction, it was seen that the up values of the stations listed above are increased.

The highest linear motion was calculated at the SARV_3 station with a value of $29.75 \mathrm{~mm}$ /year and the lowest linear motion was calculated at the YOZ1_2 station with a value of $0.10 \mathrm{~mm}$ /year. Linear movements in up coordinates of GURU, AKSR, CANK_1, CANK_2, KAMN, CIHA, ANKR, SARV_1, KNY1, SIH1_3, AKHR, KAP1, BOG1, NIV1, and AKD1_1 stations are in (-) negative direction. In the up time series, the largest linear movement was detected at KNY1 station with a value of $-48.22 \mathrm{~mm} /$ year and the smallest linear movement was determined at station NEV1 with a value of $-0.15 \mathrm{~mm} /$ year. In addition, a change of approximately $-22.41 \mathrm{~mm} / \mathrm{year}$ is observed at KAP1 station (Table 4). It is thought that the KNY1 and KAP1 stations are located in the areas where the groundwater level decreases in the Konya Closed Basin, and the negative ( - ) change in these stations is related with the decrease in the water level. Many studies have been carried out on the decrease in groundwater level in this region. See for detailed information; Üstün et al. 2007; Üstün et al. 2015; Özdemir, 2014; Orhan et al. 2020; Orhan 2021. 
Table 4. Linear models and annual rates of GNSS stations (Eurasian-fixed frame)

\begin{tabular}{|c|c|c|c|c|c|c|c|c|}
\hline $\begin{array}{l}\text { Station } \\
\text { Name }\end{array}$ & $\begin{array}{l}y(\mathrm{ti})=a+b t \text { NORTH } \\
\text { Linear Model }\end{array}$ & $\begin{array}{l}\text { Speed }= \\
365^{*} \mathrm{~b} \\
(\mathrm{~mm} / \text { year })\end{array}$ & $\begin{array}{l}\mathrm{y}(\mathrm{ti})=\mathrm{a}+\mathrm{bt} \text { EAST Linear } \\
\text { Model }\end{array}$ & \begin{tabular}{|l|} 
Speed $=$ \\
$365^{*} \mathrm{~b}$ \\
$(\mathrm{~mm} /$ year
\end{tabular} & $\begin{array}{l}\text { Result } \\
(\mathrm{mm} / \mathrm{J}\end{array}$ & $\begin{array}{l}\text { it Speed } \\
\text { ar) }\end{array}$ & $\begin{array}{l}\mathrm{y}(\mathrm{ti})=\mathrm{a}+\mathrm{bt} \\
\text { Up Linear Model }\end{array}$ & $\begin{array}{l}\text { Speed }= \\
365^{*} \text { b } \\
\text { (mm/year) }\end{array}$ \\
\hline BASK_1 & $\mathrm{y}(\mathrm{ti})=1.341+0.0425 \mathrm{t}$ & 15.51 & $y(t i)=-2.5443-0.0133 t$ & \begin{tabular}{|l|}
-4.84 \\
\end{tabular} & 16.25 & Northwest & $y(t i)=-5.1855+0.0193 t$ & 7.04 \\
\hline BASK_2 & $y(t i)=0.0217+0.0419 t$ & 15.29 & $y(t i)=-1.7058-0.0126 t$ & -4.61 & 15.97 & Northwest & $\mathrm{y}(\mathrm{ti})=8.6337+0.0138 \mathrm{t}$ & 5.02 \\
\hline GURU & $y(t i)=0.7210+0.0252 t$ & 9.19 & $y(t \mathrm{ti})=-0.1948-0.0438 \mathrm{t}$ & -15.99 & 18.44 & Northwest & $y(\mathrm{ti})=1.6579-0.0006 \mathrm{t}$ & -0.22 \\
\hline $\begin{array}{l}\text { SIVS_1 } \\
\end{array}$ & $y(t i)=0.3337+0.0194 t$ & 7.08 & $y(t i)=-0.3377-0.0439 t$ & -16.01 & 17.50 & Northwest & $y(t)=-3.1008+0.0163 t$ & 5.97 \\
\hline SIVS_2 & $y(t i)=-2.1542+0.0236 t$ & 8.63 & $y(\mathrm{ti})=-4.4541-0.0497 \mathrm{t}$ & -18.13 & 20.08 & Northwest & $y(t i)=-21.3763+0.0042 t$ & 1.52 \\
\hline GEME & $y(t i)=-7.7208+0.0247 t$ & 9.01 & $y(t)=-2.3107-0.0418 t$ & -15.25 & 17.71 & Northwest & $y(\mathrm{ti})=-0.9210+0.0033 \mathrm{t}$ & 1.22 \\
\hline KAYS & $y(t i)=-0.1221+0.0181 t$ & 6.61 & $\mathrm{y}(\mathrm{ti})=0.0131-0.0442 \mathrm{t}$ & -16.14 & 17.44 & \begin{tabular}{|l|} 
Northwest \\
\end{tabular} & $\mathrm{y}(\mathrm{ti})=3.6273+0.0003 \mathrm{t}$ & 0.11 \\
\hline YOZ1_1 & $y(t i)=0.8331+0.0103 t$ & 3.75 & $y(t)=3.2804-0.0480 t$ & -17.53 & 17.92 & Northwest & $\mathrm{y}(\mathrm{ti})=-5.2383+0.0119 \mathrm{t}$ & 4.35 \\
\hline YOZ1_2 & $y(\mathrm{ti})=3.2809+0.0130 \mathrm{t}$ & 4.76 & $y(\mathrm{ti})=-0.3345-0.0511 \mathrm{t}$ & -18.64 & 19.24 & Northwest & $y(\mathrm{ti})=-6.5517+0.0003 t$ & 0.10 \\
\hline NIGD & $y(t i)=-0.0879+0.0146 t$ & 5.31 & $y(t i)=-1.6882-0.0408 t$ & -14.89 & 15.81 & Northwest & $y(t i)=-23.8459+0.0016 t$ & 0.59 \\
\hline HALP & $y(t \mathrm{ti})=1.1983+0.0151 \mathrm{t}$ & 5.53 & $y(t i)=-0.8474-0.0387 t$ & -13.41 & 14.50 & Northwest & $y(\mathrm{ti})=-6.7455+0.0028 \mathrm{t}$ & 1.04 \\
\hline AKSR & $y(t \mathrm{ti})=-1.3001+0.0085 t$ & 3.10 & $\mathrm{y}(\mathrm{ti})=2.8935-0.0516 \mathrm{t}$ & -18.82 & 19.07 & Northwest & $y(t i)=-14.5906-0.0205 t$ & -7.48 \\
\hline CANK_1 & $\mathrm{y}(\mathrm{ti})=1.9777-0.0017 \mathrm{t}$ & $\begin{array}{l}-0.63 \\
\end{array}$ & $y(t i)=-2.5724-0.0482 t$ & -17.59 & 17.60 & Southwest & $y(t i)=-0.8255-0.0009 t$ & -0.33 \\
\hline CANK_2 & $y(t i)=-1.8853+0.0180 t$ & 6.56 & $y(\mathrm{ti})=-1.0364-0.0439 \mathrm{t}$ & -16.01 & 17.31 & Northwest & $y(t i)=5.6662-0.0141 t$ & -5.15 \\
\hline KKAL & $y(t i)=-0.4284+0.0038 t$ & 1.39 & $\mathrm{y}(\mathrm{ti})=1.5088-0.0578 \mathrm{t}$ & -21.11 & 21.16 & Northwest & $y(t i)=-12.8039+0.0030 t$ & 1.08 \\
\hline KAMN & $y(t i)=-1.4761+0.0119 t$ & 4.36 & $y(t)=0.1776-0.0336 t$ & -12.28 & 13.03 & Northwest & $y(t)=-19.9852-0.0137 t$ & -5.00 \\
\hline KLUU & $y(t i)=-1.1815+0.0074 t$ & 2.70 & $y(t i)=-1.3936-0.0522 t$ & -19.04 & 19.23 & Northwest & $y(t i)=-0.5096+0.0032 t$ & 1.19 \\
\hline$\overline{\mathrm{CIHA}}$ & $y(\mathrm{ti})=0.9653-0.0012 \mathrm{t}$ & -0.45 & $\mathrm{y}(\mathrm{ti})=1.4483-0.0563 \mathrm{t}$ & -20.55 & 20.55 & Southwest & $\mathrm{y}(\mathrm{ti})=1.0117-0.0079 \mathrm{t}$ & -2.89 \\
\hline ANRK_1 & $\mathrm{y}(\mathrm{ti})=2.0997-0.0002 \mathrm{t}$ & -0.06 & $y(t i)=0.4200-0.0621 t$ & -22.66 & 22.66 & \begin{tabular}{|l|} 
Southwest \\
\end{tabular} & $\mathrm{y}(\mathrm{ti})=-5.7743+0.0111 \mathrm{t}$ & 4.06 \\
\hline ANRK_2 & $y(t \mathrm{ti})=-0.7142+0.0006 \mathrm{t}$ & 0.23 & $y(t)=0.5205-0.0565 t$ & -20.64 & 20.64 & Northwest & $y(t i)=-4.8296+0.0135 t$ & 4.93 \\
\hline ANKR & $y(t \mathrm{ti})=-0.1372-0.0023 \mathrm{t}$ & $\begin{array}{l}-0.82 \\
\end{array}$ & $y(\mathrm{ti})=-2.1792-0.0638 \mathrm{t}$ & -23.29 & 23.31 & Southwest & $\mathrm{y}(\mathrm{ti})=-13.43-0.0124 \mathrm{t}$ & -4.54 \\
\hline SARV_1 & $y(t i)=1.8299+0.0077 t$ & 2.81 & $y(t i)=-1.4094-0.0421 t$ & -15.36 & 15.61 & Northwest & $y(t i)=-12.3092-0.0047 t$ & -1.72 \\
\hline SARV_2 & $y(t i)=4.1808-0.0233 t$ & -8.49 & $y(t i)=-6.1333-0.0213 t$ & -7.76 & 11.50 & Southwest & $y(t i)=-12.0975+0.0706 t$ & 25.76 \\
\hline SARV_3 & $y(t i)=4.5048+0.0149 t$ & 5.45 & $y(t i)=-0.2086-0.0600 t$ & -21.90 & 22.57 & Northwest & $y(t i)=7.528+0.0815 t$ & 29.75 \\
\hline KNY1 & $y(t i)=5.7047+0.0217 t$ & 7.93 & $y(t i)=-5.6043-0.0505 t$ & -18.42 & 20.06 & Northwest & $y(\mathrm{ti})=-42.4959-0.1321 \mathrm{t}$ & -48.22 \\
\hline CALM_1 & $\mathrm{y}(\mathrm{ti})=1.6803-0.0046 \mathrm{t}$ & -1.66 & $y(t i)=1.4626-0.0540 t$ & $\begin{array}{l}-19.71 \\
\end{array}$ & 19.78 & Southwest & $y(t i)=-3.4678+0.0065 t$ & 2.38 \\
\hline CALM_2 & $\mathrm{y}(\mathrm{ti})=0.5128-0.0043 \mathrm{t}$ & -1.58 & $\mathrm{y}(\mathrm{ti})=1.3307-0.0524 \mathrm{t}$ & -19.14 & 19.21 & Southwest & $y(\mathrm{ti})=-4.3832+0.0011 \mathrm{t}$ & 0.39 \\
\hline BEYS & $\mathrm{y}(\mathrm{ti})=0.4754-0.0076 \mathrm{t}$ & -2.77 & $y(t i)=-0.4252-0.0436 t$ & -15.92 & 16.15 & Southwest & $y(\mathrm{ti})=-9.6745+0.0047 t$ & 1.70 \\
\hline YUN1_1 & $y(t \mathrm{ti})=-0.7425-0.0068 \mathrm{t}$ & -2.48 & $y(\mathrm{ti})=1.006-0.0575 \mathrm{t}$ & -20.99 & 21.13 & \begin{tabular}{|l|} 
Southwest \\
\end{tabular} & $y(t)=0.1629+0.0139 t$ & 5.08 \\
\hline YUN1_2 & $y(t \mathrm{ti})=-0.3143-0.0084 \mathrm{t}$ & -3.07 & $y(\mathrm{ti})=5.7488-0.0545 \mathrm{t}$ & -19.89 & 20.13 & \begin{tabular}{|l|} 
Southwest \\
\end{tabular} & $y(\mathrm{ti})=3.9402+0.0155 \mathrm{t}$ & 5.65 \\
\hline SIH1_1 & $y(t i)=-0.9776-0.0085 t$ & -3.10 & $y(t i)=0.1050-0.0603 t$ & -22.01 & 22.23 & Southwest & $y(t i)=1.5454+0.0105 t$ & 3.83 \\
\hline SIH1_2 & $y(t i)=0.6935-0.0193 t$ & -7.06 & $y(t i)=0.6006-0.0602 t$ & -21.98 & 23.08 & Southwest & $y(\mathrm{ti})=-2.7725+0.0125 \mathrm{t}$ & 4.57 \\
\hline SIH1_3 & $\mathrm{y}(\mathrm{ti})=2.1295-0.0230 \mathrm{t}$ & -8.40 & $y(t i)=1.6909-0.0569 t$ & 0.81 & 8.44 & Southeast & $y(\mathrm{ti})=-1.4834-0.0171 \mathrm{t}$ & -6.26 \\
\hline AKHR & $y(t i)=12.1708-0.0121 t$ & -4.42 & $y(t i)=-5.1438-0.0575 t$ & -20.97 & 21.43 & \begin{tabular}{|l|} 
Southwest \\
\end{tabular} & \begin{tabular}{|l}
$\mathrm{y}(\mathrm{ti})=4.2996-0.0096 \mathrm{t}$ \\
\end{tabular} & -3.49 \\
\hline NAHA & $y(t i)=2.3182-0.0069 t$ & -2.52 & $y(t i)=-0.3622-0.0592 t$ & -21.61 & 21.76 & Southwest & $y(t i)=-1.085+0.0068 t$ & 2.50 \\
\hline ESKS & $y(t i)=0.0218-0.0090 t$ & -3.28 & $y(t i)=2.7517-0.0586 t$ & -21.23 & 21.48 & Southwest & $y(t i)=-2.5633+0.0053 t$ & 1.85 \\
\hline BUCU & $y(\mathrm{ti})=-0.1475-0.0030 \mathrm{t}$ & -1.11 & $y(\mathrm{ti})=-0.3426+0.0010 \mathrm{t}$ & 0.36 & 1.17 & Southeast & $y(\mathrm{ti})=-1.6873+0.0059 t$ & 2.17 \\
\hline KAP1 & $y(t i)=-0.1501+0.0071 t$ & 2.60 & $y(\mathrm{ti})=1.481-0.0513 \mathrm{t}$ & -18.74 & 18.92 & Northwest & $y(t i)=0.5663-0.0614 t$ & -22.41 \\
\hline SSE1 & $y(\mathrm{ti})=0.6549+0.0164 \mathrm{t}$ & 5.98 & $y(t i)=0.3114-0.0289 t$ & -10.54 & 12.12 & Northwest & $y(t i)=-2.0701+0.0046 t$ & 1.67 \\
\hline BOG1 & $y(\mathrm{ti})=-1.6183+0.0161$ & 5.88 & $\mathrm{y}(\mathrm{ti})=4.8055-0.0530 \mathrm{t}$ & -19.34 & 20.21 & Northwest & $y(t i)=-6.6115-0.0096 t$ & -3.51 \\
\hline NIV1 & $y(t i)=2.7078+0.0187 t$ & 6.84 & $\mathrm{y}(\mathrm{ti})=2.2719-0.0471 \mathrm{t}$ & -17.21 & 18.52 & Northwest & $\mathrm{y}(\mathrm{ti})=2.5191-0.0004 \mathrm{t}$ & -0.15 \\
\hline$\overline{\text { AKD1_1 }}$ & $y(t i)=-3.6114+0.0371 t$ & 13.53 & $y(t i)=-4.554-0.0439 t$ & -16.01 & 20.96 & Northwest & $\mathrm{y}(\mathrm{ti})=-21.0493-0.0254 \mathrm{t}$ & -9.28 \\
\hline$\overline{\text { AKD1_2 }}$ & $\mathrm{y}(\mathrm{ti})=3.1354+0.0192 \mathrm{t}$ & 7.01 & $y(t i)=9.3971-0.0552 t$ & -20.16 & 21.35 & Northwest & $\mathrm{y}(\mathrm{ti})=-2.2247+0.0043 \mathrm{t}$ & 1.56 \\
\hline ANK2 & $\mathrm{y}(\mathrm{ti})=2.1425-0.0012 \mathrm{t}$ & -0.44 & $y(t i)=0.5857-0.0664 t$ & -24.25 & 24.26 & Southwest & $y(t i)=-0.8576+0.0148 t$ & 5.41 \\
\hline KIS1 & $y(t \mathrm{ti})=-2.1063+0.0155 \mathrm{t}$ & 5.64 & $y(t i)=-1.9041-0.0548 t$ & -20.01 & 20.79 & Northwest & $\mathrm{y}(\mathrm{ti})=3.4692+0.0183 \mathrm{t}$ & 6.69 \\
\hline
\end{tabular}

In Table 4, the average horizontal movement (resultant velocity) was found to be $18.24 \mathrm{~mm} /$ year in the northwest direction and $18.66 \mathrm{~mm} /$ year in the southwest direction. When the results obtained for the horizontal component from this study compared with other studies that given in Figure 5, such as, the velocity value of $20 \mathrm{~mm} /$ year in the southwest direction obtained from Cingöz et al. (2013), and 
value of $21.72 \mathrm{~mm} /$ year obtained by Gülal et al. 2013 and the velocity of $20.52 \mathrm{~mm} /$ year by Güçlü 2021, around Kirlkkale, it is seen that the velocity values obtained from this study is in agreement with these studies.

In addition, it has been shown that the Anatolian Plate has a westward linear movement with a velocity of 13-27 mm/year (Şentürk, 2019) and the North Anatolian Fault Zone has a westward movement of approximately $25 \mathrm{~mm} /$ year relative to the Eurasian Plate (Aktuğ, 2006). In the study conducted by Tiryakioğlu (2012), it was determined that the velocities parallel to the fault was approximately $22 \mathrm{~mm} /$ year at the points in Southwest Anatolia and the north of the FethiyeBurdur Fault Zone.

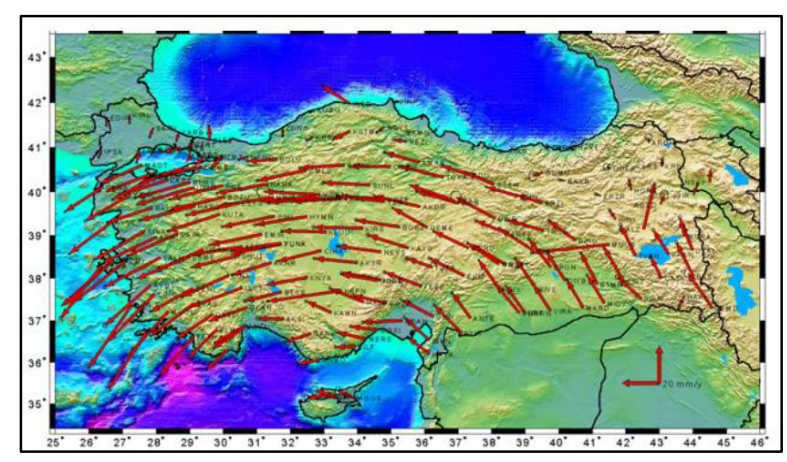

Figure 5. Point velocities (Eurasia fixed) (Cingöz et al., 2013)

It has also been determined that the results obtained from this study in the vertical component are in agreement with the vertical velocity values given in Figure 6.

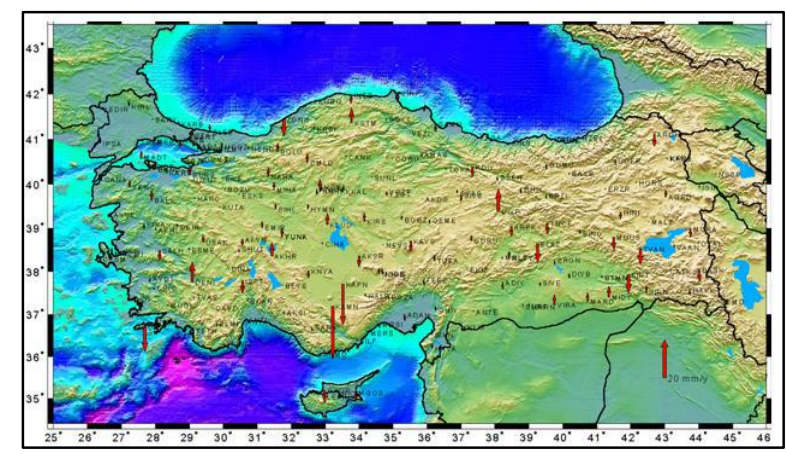

Figure 6. Point velocities (vertical) (Özdemir et al., 2011)

Additionally, the standard deviation values ( $\left.\mathrm{m}_{0}\right)$ of the linear changes in the time series were also calculated. The $\mathrm{m}_{0}$ values calculated for each station as a result of the adjustment in the north, east and Up directions, are given in Figure 7, 8 and 9. As it is seen (Figure 7, 8, 9), for the north direction of the stations, the $m_{0}$ values are in the range of approximately 1-4 $\mathrm{mm}$, excluding SARV_1 $\left(\mathrm{m}_{0}=4.89 \mathrm{~mm}\right)$, and KAP1 $\left(\mathrm{m}_{0}=4.25 \mathrm{~mm}\right)$ stations, for the east direction, SARV_3 $\left(\mathrm{m}_{0}=4.72 \mathrm{~mm}\right)$ station. It is seen that the $\mathrm{m}_{0}$ values are in the range of $0.8-3.5 \mathrm{~mm}$ except for the up direction, the biggest standard deviation is KNY1 $\left(\mathrm{m}_{0}=18.01 \mathrm{~mm}\right)$ station and the other stations $\mathrm{m}_{0}$ values are in the range of 3-13 $\mathrm{mm}$. Due to the insufficient number of data (data gap), the mo values of the SARV station, which were examined in three parts, were found to be higher than the other stations.

While the obtained $m_{0}$ values are approximately same for the north and east directions, it can be stated that the Up values are approximately 2-3 times greater than the north or east directions. As it is known, the fact that the sensitivity of the up component determined by GNSS is 2-3 times worse than the horizontal position sensitivity is also seen in the results obtained here.

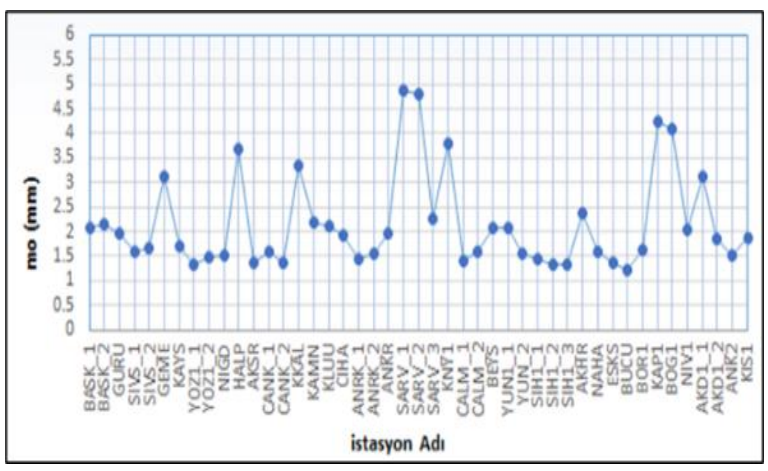

Figure 7. North direction linear variations standard deviations $\left(\mathrm{m}_{0}\right)$

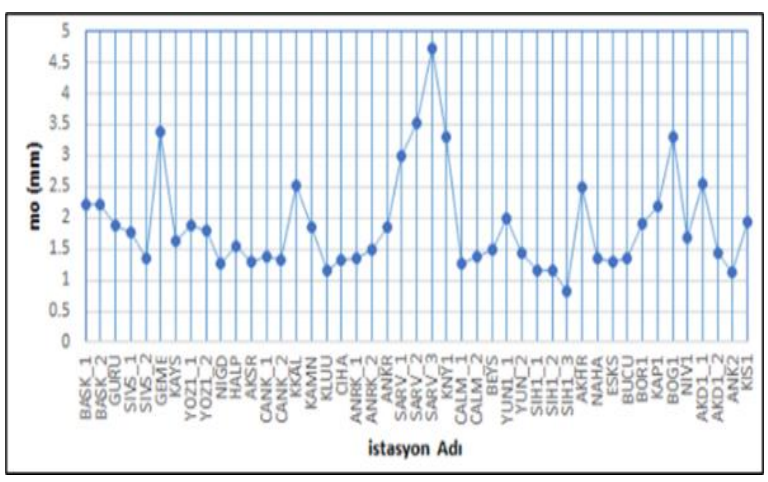

Figure 8. East direction linear variations standard deviations $\left(\mathrm{m}_{0}\right)$

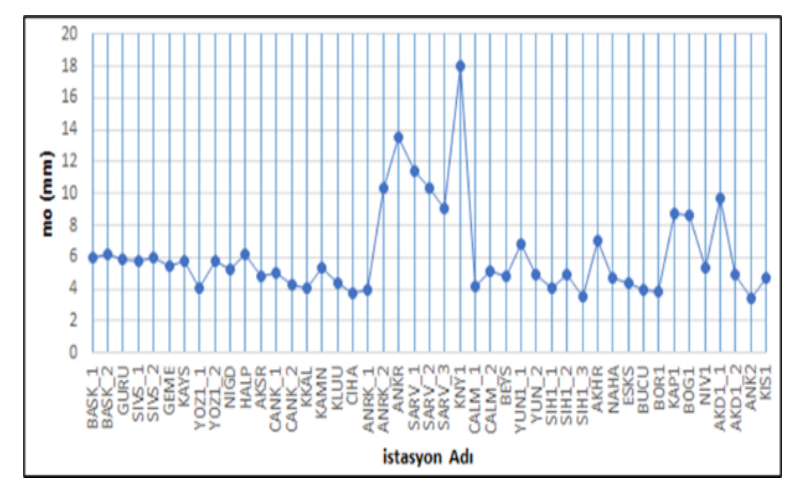

Figure 9. Up direction linear variations standard deviations $\left(\mathrm{m}_{0}\right)$ 


\section{RESULTS}

Since Turkey is located at the intersection of Arabian, Anatolian and Eurasian tectonic plates, annual changes occur in point positions at the rank of $\mathrm{cm}$ due to the movement of these plates. For this reason, obtaining, evaluating, analyzing (time series analysis) and calculating the velocity values of GNSS stations at certain time intervals (daily, monthly, etc.) are important in terms of determining the position accuracy of the GNSS sites and ensuring their continuity.

In this study; The linear behaviors in the North, East and Up directions of 30 CORS-TR GNSS stations located in the Central Anatolian Region were obtained with the trend component analysis, which is the time series analysis component. The time series of the stations between the years of 2017 2020 were calculated with the GAMIT/GLOBK software, taking Eurasia plate as constant.

In the result of the analysis, it is obtained that the BASK_1, BASK_2, GURU, SIVS_1, SIVS_2, GEME, KAYS, YOZ1_1, YOZ1_2, NIGD, HALP, AKSR, CANK_2, KKAL, KAMN, KLUU, ANRK_2, SARV_1, SARV_3, KNY1, KAP1, SSE1, BOG1, NIV1, AKD1_1, AKD1_2 and KIS1 stations have an average horizontal velocity of $17.59 \mathrm{~mm} /$ year in the northwest direction and CANK_1, CIHA, ANRK_1, ANKR, SARV_2, CALM_1, CALM_2, BEYS, YUN1_1, YUN_2, SIH1_1, SIH1_2, AKHRSI , ESKS, BUCU and ANK2 stations have an average horizontal velocity of $18.66 \mathrm{~mm} /$ year in the southwest direction. This shows the movement of the Anatolian plate in the southwest direction in terms of movement direction and velocity value and is consistent with other research results.

In the linear changes in the Up coordinates of the stations, the largest linear movement in the $\left.{ }^{+}\right)$ positive direction was determined at the SARV_3 station with $29.75 \mathrm{~mm} /$ year values, and the largest linear movement in the negative $(-)$ direction was determined at the KNY1 station with the values of $48.22 \mathrm{~mm} /$ year. Also, $22.41 \mathrm{~mm} /$ year change was observed in the Up coordinate in negative direction at the KAP1 station. It is thought that the negative () change in these station is occurred due to the decrease in the groundwater level in this region (Konya Closed Basin).

In addition, standard deviation values ( $\left.\mathrm{m}_{0}\right)$ were calculated as a result of the analysis of the linear changes of time series, and due to the high number of data loss, the mo values of the SARV station, which were examined in three separate parts, were found to be large than the other stations. While the obtained $m_{0}$ values are approximately the same for the north and east directions, it can be stated that the Up values are approximately $2-3$ times larger than the north or east directions. As it is known, the sensitivity of the Up values determined by GNSS is 2-3 times worse than the horizontal position sensitivity, is also seen in the results obtained from this study.

\section{Acknowledgement}

This article was produced from Abdulmalek REDHWAN's master thesis.

\section{Author Contributions}

Abdulmalek Redhwan: Methodology, Software, Validation, Formal analysis, Writing-Original Draft, Visualization. Hediye Erdoğan: Supervision, Writing-Original Draft. Osman Oktar: Methodology, Software, Formal analysis. Cemil Gezgin: WritingReview \& Editing, Visualization.

\section{Conflicts of Interest}

The authors declare no conflict of interest

\section{REFERENCES}

Aktuğ, B. (2006). Determination of earthquake source parameters through geodetic observations (PhD thesis). Istanbul Technical University, Istanbul, Turkey (in Turkish).

Cingöz, A., Erkan, Y., Kurt, Y.A., \& Peker, S. (2013). Turkey national fixed gnss network-active (TUSAGA-Active) system. TMMOB Chamber of Surveying and Cadastre Engineers, 14. Turkey Map Scientific and Technical Congress, Ankara.

Gezgin, C., Tiryakioğlu, İ., Ekercin, S., \& Gürbüz, E. (2020). Monitoring of tectonic movements of the southern section of the Tuz Gölü fault zone (TGFZ) with GNSS observations. Afyon Kocatepe University Journal of Science and Engineering, 20(3), 456-464.

Güçlü, A.T. (2021). Definition of behavior of GNSS stations in Kırlkkale and surrounding (MSc thesis). Aksaray University, Aksaray, Turkey (in Turkish).

Gülal, E., Aykut, N.O., Akpınar, B., Tiryakioğlu, İ., Dindar, A.A., \& Erdoğan, H. (2013). Establishment of Yildiz Technical University fixed GNSS station, analysis and presentation of data, 14. Turkey Map Scientific Technical Congress, Ankara.

Mutlu, İ., \& Kahveci, M. (2019). The importance of GNSS satellite distribution in Real-Time Kinematics GNSS and Network-RTK measurements. Geomatics, 4(3), 179-189.

Oktar, 0. (2015). Identification of behavior of stationary GNSS stations with wavelet transform (MSc thesis). Aksaray University, Aksaray, Turkey (in Turkish).

Oktar, O., \& Erdogan, H. (2018). Research of behaviours of continuous GNSS stations by 
signal. Earth Sciences Research Journal, 22(1), 19-27.

Orhan, O., Yakar, M., \& Ekercin, S. (2020). An application on sinkhole susceptibility mapping by integrating remote sensing and geographic information systems. Arabian Journal of Geosciences, 13,17, 1-17.

Orhan, O. (2021). Monitoring of land subsidence due to excessive groundwater extraction using small baseline subset technique in Konya, Turkey. Environmental Monitoring and Assessment, 193(4), 1-17.

Orhan, O., Oliver-Cabrera, T., Wdowinski, S., Yalvac, S., \& Yakar, M. (2021). Land subsidence and its relations with sinkhole activity in Karapınar region, Turkey: a multi-sensor InSAR time series study. Sensors, 21(3), 774.

Ostini, L. (2012). Analysis and quality assessment of GNSS-derived parameter time series (PhD thesis). Bern University, Bern, Switzerland.

Özdemir, S. (2014). Analysis of GNSS time series obtained from Turkish national permanent GNSS stations network-active system using Hilbert-Huang transform (MSc thesis). Middle East Technical University, Ankra Turkey.

Özdemir, S., Cingöz, A., Aktuğ, B., Lenk, O., Kurt, M., \& Parmaksız, E. (2011). Analysis of fixed station data. TMMOB Chamber of Surveying and Cadastre Engineers 13th Turkish Scientific and Technical Mapping Congress, 18-22.

Özdoğan, S. (1993). Turkey's earthquake zones. Journal of Turkish Geography Research and Application Center, 2, 53-68.

Şentürk, M.D. (2019). Optimal filtering of strong motion records with GPS (MSc thesis). Ankara University, Ankara, Turkey (in Turkish).
Tiryakioğlu, İ. (2012). identification of the block movements and stress zones in southwestern anatolia with GNSS measurements ( $\mathrm{PhD}$ thesis). Ylldız Technical University, İstanbul, Turkey (in Turkish).

Uzel, T., Eren, K., Gulal, E., Tiryakioglu, I., Dindar, A. A., \& Yilmaz, H. (2013). Monitoring the tectonic plate movements in Turkey based on the national continuous GNSS network. Arabian Journal of Geosciences, 6(9), 3573-3580.

Üstün, A., Tuşat, E., \& Abbak, R.A. (2007). Groundwater withdrawal in Konya Closed Basin and geodetic monitoring of possible consequences. 3. Engineering Symposium, 2426.

Üstün, A., Tuşat, E., Yalvaç, S., Özkan, İ., Eren, Y., Özdemir, A., \& Doğanalp, S. (2015). Land subsidence in Konya Closed Basin and its spatiotemporal detection by GPS and DInSAR. Environmental earth sciences, 73,10, 6691-6703.

Yalvaç, S. (2020). Determining the effects of the 2020 Elazığ-Sivrice/Turkey (Mw 6.7) earthquake from the surrounding CORS-TR GNSS stations. Turkish Journal of Geosciences, 1(1), 15-21.

Yavaşoğlu, H., Tarı, E., Tüysüz, O., Çakır, Z., \& Ergintav, S. (2011). Determining and modeling tectonic movements along the central part of the North Anatolian Fault (Turkey) using geodetic measurements. Journal of Geodynamics, 51,5, 339-343.

Url-1: http://geoweb.mit.edu/gg/GAMIT_Ref.pdf, (last accessed 10 July 2020)

Url-2: http://tusaga.Aktif.gov.tr/Sayfalar/ Rinex/ 30 sn Rinex.aspx, (last accessed 4 July 2020)

(C) Author(s) 2021. This work is distributed under https://creativecommons.org/licenses/by-sa/4.0/ 